\title{
PELAKSANAAN KELAS DIGITAL PARENTING BERTEMA CARA MENCEGAH KECANDUAN GADGET DI MASA GOLDEN $A G E$
}

\author{
Mayrina Eka Prasetyo Budi \\ Jurusan Bimbingan Penyuluhan Islam IAIN Ponorogo \\ mayrinaekapb@gmail.com
}

\begin{abstract}
Parenting classes in the form of sharing classes, which are classes where parents share knowledge about parenting. Through parenting classes, parents will gain knowledge about various parenting techniques. Seeing the phenomenon of early childhood addiction to gadgets more and more especially during the corona pandemic, encouraging The Inclusion Kindergarten of the Shaleh Children Islamic Boarding School (PAS) Baitul Qur'an Ponorogo held a digital parenting class with the thema of preventing gadget addiction during the golden age. This study aims to describe the process of implementing digital parenting classes carried out by the Baitul Qur'an Ponorogo Kindergarten. The study used a descriptive qualitative method. The results showed that the digital parenting class with the theme of preventing addiction, gadgets in the golden age was carried out on October 19, 2020 properly via zoom. There are four materials presented, namely the position of children in Islamic perspective, data on the number of children who experience gadget addiction, characteristics of gadget addiction, negative effects of gadgets, and how to prevent golden age children from becoming addicted to gadgets. All participants are very enthusiastic about taking digital parenting calles from start to finish. Through this activity parents have knowledge about how to prevent gadget addiction during the golden age.
\end{abstract}

Keywords: digital parenting classes, how to prevent gadget addiction, the golden age.

\begin{abstract}
Abstrak
Kelas parenting dalam bentuk sharing class yaitu kelas yang menjadi tempat para orang tua untuk berbagi ilmu tentang pengasuhan. Melalui kelas parenting orang tua akan memperoleh pengetahuan tentang berbagai tehnik pengasuhan. Melihat fenomena anak usia dini yang kecanduan gadget semakin banyak, apalagi di masa pandemi corona mendorong sekolah TK Inklusi Pesantren Anak Shaleh (PAS) Baitul Qur'an Ponorogo
\end{abstract}


mengadakan kelas digital parenting bertema cara mencegah kecanduan gadget di masa golden age. Penelitian ini bertujuan untuk mendeskripsikan proses pelaksanaan kelas digital parenting yang dilaksanakan oleh TK Inklusi Baitul Qur'an Ponorogo. Penelitian menggunakan metode kualitatif deskriptif. Hasil penelitian menunjukkan bahwa kelas digital parenting bertema cara mencegah kecanduan gadget di masa golden age sudah dilaksanakan pada tanggal 19 Oktober 2020 dengan baik via zoom. Ada empat materi yang disampaikan yaitu kedudukan anak dalam kacamata Islam, data jumlah anak yang mengalami kecanduan gadget, ciri-ciri kecanduan gadget, dampak negatif gadget, dan cara mencegah anak usia golden age dari kecanduan gadget. Semua peserta sangat antusias mengikuti kelas digital parenting dari awal sampai akhir. Melalui kegiatan ini orang tua memiliki pengetahuan tentang cara mencegah kecanduang gadget di masa golden age

\section{Kata kunci : kelas digital parenting, cara mencegah kecanduan gadget, masa golden age}

\section{PENDAHULUAN}

Pola asuh memiliki pengaruh besar di masa golden age. Orang tua berperan penting dalam mengoptimalkan tumbuh kembang anak, sehingga dikatakan orang tua adalah penentu bagi masa depan anak. ${ }^{1}$ Kualitas pengasuhan mempengaruhi perkembangan anak. Berbagai penelitian menunjukkan bahwa pengasuhan merupakan faktor utama yang mempengaruhi perkembangan $a_{n}{ }^{2}$. Di usia dini sangat diperlukan pola asuh orang tua yang tepat dalam rangka menstimulasi tumbuh kembang anak secara optimal. Secara terminologi, pola asuh adalah cara yang ditempuh orang tua dalam mendidik anak sebagai perwujudan dari tanggung jawab kepada anak ${ }^{3}$.

Pola asuh yang kurang tepat sering dijumpai di tengah masyarakat. Hal itu terjadi karena banyak orang tua hanya memiliki sedikit persiapan untuk mengasuh anak. Orang tua mengasuh anak lewat proses trial dan error ${ }^{4}$. Salah satu pola asuh yang tidak tepat

${ }^{1}$ Tri Suhardi dan Esti Utami. Ayah \& Bunda, Mengatasi Kecanduan Gadget pada Anak. (Semarang: Syalmahat Publishing,2019), 26.

2 Sanders, M.R, "Triple P-Positive Parenting Program as a Public Health Approach to Strengthening Parenting", Journal of Family Psychology, 506-51 (2008).

${ }^{3}$ Maya, R.R., Risma, F., Sari, R dan Lubis, H "Peran Pola Asuh Orang Tua dalam Membentuk Karakter Peduli Lingkungan”., Jurnal Psikostudia, Vol.7, No.2, 61-70 (2018).

${ }^{4}$ Sanders, M.R., Dadds, C.M., dan Turner, K.M. Theoretical, Scientific and Clinical Foundations of the Triple P-Positive Parenting Program: A Population Approach to the Promotion of Parenting Competence. (Queensland: The University of Queensland,2003). 
yaitu membiarkan anak usia dini bermain gadget tanpa batasan dan pendampingan. Para orang tua memberikan gadget agar anak duduk tenang, dan tidak rewel, sehingga tidak mengganggu aktifitas mereka. Sekitar $70 \%$ orang tua mengaku mengijinkan anak-anak mereka yang usianya enam bulan sampai empat tahun bermain gadget ketika mereka sedang melakukan pekerjaan rumah tangga, serta sekitar 65\% melakukan hal yang sama untuk menenangkan anak saat berada di tempat umum, dan satu perempat orang tua mengaku meninggalkan anak-anak mereka sendiri dengan gadget menjelang tidur ${ }^{5}$. Zaini dan Soenarto menemukan tingkat penggunaan smartphone pada anak usia TK 4-6 tahun sebesar sembilan puluh empat persen ${ }^{6}$.

Orang tua belum memahami pemberian gadget akan membawa dampak negatif pada anak. Salah satu dampak negatif gadget yaitu terjadinya gadget addiction atau kecanduan gadget. Pemberian gadget di usia dini memperbesar kemungkinan anak akan mengalami kecanduan. Ketua Komisi Perlindungan anak Indonesia (KPAI) Susanto menyampaikan anak yang mengalami kecanduan gadget menjadi tantangan serius. Hanya saja tidak semua orang tua mengetahui anaknya teridndikasi kecanduan gawai ${ }^{7}$. Direktur Pusat Pendidikan untuk Perempuan dan Anak (PUPA) Bengkulu,Susi Handayani menyatakan di zaman sekarang anak-anak usia di bawah satu tahun sudah dikenalkan dengan gadget ${ }^{8}$. Anak usia di bawah dua tahun idealnya bebas dari gadget, sedangkan usia dua hingga lima tahun penggunaannya dibatasi satu jam per hari untuk program berkualitas disertai pendampingan orang tua. Adapun untuk anak berusia enam tahun atau lebih perlu ada batasan durasi yang konsisten ${ }^{9}$.

Banyak orang tua belum mengetahui cara mengasuh anak di era digital. Orang tua menjadikan gadget sebagai digital babysister di tengah kesibukan mereka. Hal seperti ini

\footnotetext{
${ }^{5}$ Nuryus, Zhallina(2019, 11 Desember). Kecanduan Gadget pada Usia Dini Semakin Menghawatirkan.

Diakses pada 10 Juli 2020 dari (https://www.suara.com/yoursay/ 2019/12/11/135739/kecanduan-gadget-padausia-dinisemakin-menghawatirkan).

${ }^{6}$ Muhammad, Zaini dan Soenarto."Persepsi Orangtua terhadap Hadirnya Era Teknologi Digital di Kalangan Anak Usia Dini”. Jurnal Obsesi: Jurnal Pendidikan Anak Usia Dini Vol 3, No 1, 254-264 (2019).

${ }^{7}$ Kompas. (2018,23 Juli). Kecanduan Gawai Ancam Anak-anak. Diakses pada 10 Juli 2020 dari http://kominfo.go.id/content/detail/13547/kecanduan-gawai -ancam-anak-anak/0/sorotan-media.

${ }^{8}$ Rajiman, Azhar. (2019, 18 Desember). 70 Persen Anak Kecanduan Gadget. Diunduh pada 19 Februari 2020, dari https://bengkuluekspress.com/70-persen-anak-kecanduan-gadget.

${ }^{9}$ American Academy of Pediatrics Committee on Public Education. (2001). "Children, Adolencents, and Television". Pediatr. 107 (2):423-6 (2001).
} 
banyak dijumpai di masyarakat, termasuk pada orang tua siswa di TK Inklusi Pesantren Anak Shalih (PAS) Baitul Qur'an Ponorogo. Dari pengamatan, sebagian orang tua belum memahami dampak negatif gadget. Sebagian orang tua sudah memahami dampak negatif gadget, akan tetapi mereka belum mengetahui cara mencegah anak kecanduan gadget. Orang tua perlu mendapatkan pengetahuan tentang digital parenting. Digital parenting menurut Jenifer merupakan strategi pengasuhan orang tua terkait aturan penggunaan perangkat digital baik online maupun offline untuk melindungi keselamatan anak dari ancaman penggunaannya ${ }^{10}$. Digital parenting adalah batasan yang dilakukan orangtua kepada anak mengenai boleh atau tidak dalam penggunaan perangkat digital, seperti komputer telepon genggam (handphone), telepon cerdas (smartphone), dan lain sebagainya ${ }^{11}$. Guna memberikan pengetahuan tentang digital parenting, maka sekolah TK Inklusi Pesantren Anak Shalih (PAS) Baitul Qur'an Ponorogo mengadakan kelas digital parenting.

Beberapa penelitian telah membahas tentang digital parenting. Khusnul Laely dkk meneliti kegiatan parenting di dua lembaga PAUD yang dirintis di Kabupaten Magelang. Hasil penelitian menunjukkan melalui kegiatan parenting orang tua memiliki pengetahuan tentang ke-PAUDan sebagai bekal dalam melakukan pengasuhan terhadap anak guna mendukung terwujudnya PKBM di daerah miskin dan desa bertekat akan meningkatkan pendidikan khususnya Anak Usia Dini untuk mewujudkan peningkatan kualitas SDM, serta mendukung terwujudnya program Kabupaten Magelang yang lebih SEMANAH (Sejahtera, Maju, dan Amanah) ${ }^{12}$. Penelitian Sri Maisari dan Sigit Purnama mendeskripsikan penerapan konsep digital parenting yang dilakukan orang tua terhadap anak usia 5-6 tahun di RA Bunayya Giwangan dan mengetahui peran digital parenting terhadap perkembangan berpikir logis anak anak usia 5-6 tahun. Hasil penelitian menunjukkan bahwa penerapan konsep digital parenting meliputi: menerapkan aturan dan

\footnotetext{
${ }^{10}$ Jennifer A Rode, "Digital Parenting: Designing Children's Safety dalam British Computer Society", London, 6 (12): 244-251 (2009)

${ }^{11}$ Giovanna, Mascheroni dkk. Digital Parenting: The Challengs for Families in The Digital Age. (Nordocom University of Gothenburg: The International Clearinghouse on Children, Youth and Media, 2018)

${ }^{12}$ Khusnul Laely dkk. Parenting Pengasuhan di Era Digital dalam Rnagka Mendukung Terwujudnya PKBM (Pusat Kegiatan Belajar Masyarakat) di Daerah Miskin. The 6th University Research Colloqium. Universitas Muhammadiyah Magelang. 1 - 7 (2017).
} 
kesepakatan terkait penggunaan gadget, membimbing dan mendampingi anak, menggunakan parental control, dan menyeimbangkan dunia digital anak dengan dunia nyata; dan peran digital parenting terhadap berpikir logis anak meliputi: sebagai edukasi sekaligus hiburan bagi anak; menstimulasi berpikir logis; mengontrol, membimbing anak dan sebagai usaha untuk menghindari kecanduan gadget ${ }^{13}$.

Beberapa penelitian terdahulu belum ada yang membahas tentang kelas digital parenting bertema cara mencegah kecanduan gadget di masa golden age. Penelitian ini berfungsi untuk melengkapi penelitian yang sudah ada sebelumnya. Rumusan masalah penelitian ini adalah bagaimana proses pelaksanaan kelas digital parenting tentang cara mencegah kecanduan gadget di masa golden age yang dilaksanakan oleh TK Inklusi Baitul Qur'an Ponorogo. Tujuan penelitian ini yaitu mendeskripsikan proses pelaksanaan kelas digital parenting tentang cara mencegah kecanduan gadget di masa golden age yang dilaksanakan oleh TK Inklusi Baitul Qur'an Ponorogo. Penelitian ini menggunakan metode kualitatif deskriptif.

\section{METODE PENELITIAN}

Penelitian ini menggunakan pendekatan kualitatif deskriptif. Penelitian deskriptif yaitu suatu penelitian sekedar untuk menggambarkan suatu variabel yang berkenaan dengan masalah yang diteliti tanpa mempersoalkan hubungan antar variabel ${ }^{14}$. Penggunaan pendekatan ini bertujuan untuk mendeskripsikan pelaksanaan kelas digital parenting tentang cara mencegah kecanduan gadget di masa golden age secara terperinci dan mendalam. Penelitian dilaksanakan di TK Inklusi Pesantren Anak Shaleh (PAS) Baitul Qur'an Ngabar Siman Ponorogo. Subyek dalam penelitian berjumlah sebelas orang tua murid. Variabel dalam penelitian ini adalah pelaksanaan kelas digital parenting.

\section{HASIL PENELITIAN DAN PEMBAHASAN}

\footnotetext{
${ }^{13}$ Sri Maisari dan Sigit Purnama. Peran Digital Parenting terhadap Perkembangan Berpikir Logis Anak Usia 5-6 tahun di RA Bunayya Giwangan. Jurnal Pendidikan Anak, Vol 5, No.1 (2019).

${ }^{14}$ Sanapiah Faisal, Format-format Penelitian Sosial (Jakarta: Rajawali Press, 1992), 18.
} 


\section{Pelaksanaan Kelas Digital Parenting di TK Inklusi PAS Baitul Qur-an Ponorogo}

Program parenting di sekolah Autis dan ABK PAS Baitul Qur'an mulai kembali bulan Oktober 2020 semenjak adanya pandemi corona. Kelas parenting atau parenting class yaitu kelas yang menjadi tempat para orang tua berbagi pengetahuan dalam mendidik anak. Keberadaan kelas parenting yang juga sebagai sharing class berfungsi sebagai sarana guna memfasilitasi para orang tyua siswa untuk berbagi dan belajar bersama. Berbagi pengalaman sebagai orang tua dan saling belajar menjadi orang tua yang baik. Melalui sharing class akan didapatkan informasi mengenai tehnik parenting terbaru yang bisa diaplikasikan di rumah. Di dalam kelas sharing dapat dibahas banyak hal khususnya tentang pengasuhan. Melihat fenomena kecanduan gadget pada anak yang semakin banyak, apalagi di era pandemi corona maka pihak sekolah mengadakan kelas digital parenting.

Kelas digital parenting yang membahas tentang cara mencegah kecanduan gadget di masa golden age dilaksanakan pada tanggal 19 Oktober 2020, pukul 9-11 WIB. Pelaksanaan dilakukan via zoom dikarenakan mematuhi protokol kesehatan di masa pandemi. Ada 11 peserta yang hadir. Acara dimulai pukul 09.00 WIB. Ibu Barokatin Minziati,S.Psi membuka acara dengan memberikan motivasi pentingnya mengikuti acara kelas digital parenting dalam rangka menambah pengetahuan yang akan menjadi bekal dalam mendidik anak. Beliau menyampaikan mendidik anak adalah tanggung jawab orang tua, apalagi di masa pandemi anak lebih banyak berada di rumah. Beliau mengajak orang tua untuk bersama-sama belajar tentang pengasuhan, khususnya tentang digital parenting.

Selanjutnya acara diserahkan kepada narasumber, yaitu peneliti. Setelah salam dan mengucapkan syukur atas segala nikmat yang Allah swt berikan, sebelum materi disampaikan narasumber menyapa peserta "Bagaimana kabar Ibu-ibu hari ini?", para peserta menjawab "Alhamdulillah, sehat". Narasumber menanggapi "Alhamdulillah semoga Ibu-ibu semuanya sehat dan selalu dalam kebaikan. Meski pandemi, Alhamdulillah Ibu-ibu tetap semangat untuk menambah ilmu yang akan menjadi bekal dalam mengasuh anak". Sapaan narasumber bertujuan untuk untuk mewujudkan suasana 
keakraban dan kenyamanan dalam forum. Acara berikutnya adalah penyampaian materi oleh narasumber. Ada lima materi yang disampaikan yaitu kedudukan anak dalam kacamata Islam, data jumlah anak yang mengalami kecanduan gadget, ciri-ciri kecanduan gadget, dampak negatif gadget, dan cara mencegah anak usia golden age dari kecanduan gadget.

Narasumber menyampaikan materi pertama yaitu kedudukan anak dalam kacamata Islam. Anak adalah permata berharga, penyejuk hati orang tua. Anak tidak hanya investasi dunia, tetapi juga investasi surga jika orang tua mampu menjadikannya anak yang shalih dan shalihah. "Jika seseorang meninggal dunia, maka terputuslah amalannya kecuali tiga perkara:sedekah jariyah, ilmu yang bermanfaat, dan do 'a anak yang shalih" (HR.Muslim no.1631). Anak harta berharga yang harus dijaga dari berbagai pengaruh negatif. Salah satunya pengaruh kecanduan gadget yang akan menghambat potensi perkembangan anak. Menjadi orang tua dibutuhkan bekal ilmu, dan keterampilan. Salah satu yang dilakukan dalam kelas digital parenting yaitu dalam rangka menambah ilmu agar bisa menjalankan kewajiban mengasuh dan mendidik anak dengan benar. Mengasuh dan mendidik anak adalah kewajiban yang pahalanya besar jika dijalankan dengan sebaik mungkin.

Memasuki materi kedua, narasumber menyampaikan saat ini adalah era digital, dan hampir semua orang terbiasa dengan gadget, bahkan sejak kecil anak sudah biasa dengan gadget. Narasumber bertanya "Bagaimana dengan Ibu-ibu yang ada disini, apakah ada yang belum pernah memberikan gadget kepada anak?". Para peserta serempak menjawab tidak sambal tersenyum dan menggelengkan kepala. Narasumber menyampaikan data jumlah anak yang kecanduan gadget dari berbagai sumber, salah satunya berasal dari Asosiasi Penyelenggara Jasa Internet Indonesia (APJII) dan Komisi Perlindungan Anak Indonesia (KPAI). Narasumber juga menyampaikan fakta banyak orang tua yang menganggap jika anak tidak diberi gadget maka akan ketinggalan jaman. Narasumber bertanya “Apakah Ibu-ibu juga demikian?". Narasumber lalu menjelaskan pandangan orang tua yang demikian sejatinya tidak tepat. Narasumber menyampaikan pernyataan dari pakar internet safety yaitu Jesse Wein Berger yang mengatakan semakin lama menahan diri untuk tidak memberikan ponsel pada anak akan semakin baik. Hal tersebut dikarenakan usia 0-6 tahun adalah masa golden age. Usia ini adalah usia anak meniru 
sikap, kata-kata dan perilaku yang ada di sekitarnya, dari apa yang dilihat, didengar dan dialaminya. Di era digital, gadget menjadi media yang dapat mempengaruhi sikap, perkataan dan perilaku anak. Narasumber menyampaikan panduan penggunaan gadget merujuk America Academy of Pediatrics (APP). Anak di bawah dua tahun jangan diberi gadget. Anak usia 2-5 tahun boleh menggunakan gadget untuk program edukatif dan maksimal satu jam sehari dan dengan pendampingan orang tua, sedangkan anak di atas enam tahun boleh diberikan gadget untuk program edukatif dengan maksimal dua jam sehari dan orang tua harus mengetahui apa yang ditonton anak ${ }^{15}$.

Selanjutnya adalah materi ketiga yaitu ciri-ciri kecanduan gadget. Narasumber menjelaskan kecanduan gadget dikenal sebagai Screen Dependency Disorder (SDD) yaitu perilaku adiksi terhadap layar gadget. SDD dapat menyerang anak usia usia berapapun. Ciri anak yang mengalami SDD yaitu terlalu asyik bermain gadget, menunjukkan perilaku yang tidak nyaman ketika tidak bermain gadget, waktu bermain gadget yang terus meningkat, gagal mengurangi atau berhenti bermain dengan gadget, kehilangan ketertarikan dengan dunia luar, tetap bermain gadget, meskipun sudah diberitahu dampak negatifnya, berbohong mengenai lama penggunaan gadget ke orang tua, menggunakan gadget untuk mengalihkan perasaan ${ }^{16}$. Intinya seorang anak dikatakan mengalami kecanduang jika sudah tidak bisa lepas dari gadget dan hal tersebut mengganggu kegiatankegiatan anak laiinnya.

Berikutnya adalah materi keempat. Narasumber menjelaskan enam dampak negatif gadget. Pertama, Gadget dapat menjadikan anak mengalami keterlambatan bicara dan bahasa. Anak akan belajar bicara dan berkomunikasi melalui interaksi dengan yang lain. Penggunaan gadget akan menjadikan anak tidak berinteraksi dengan orang lain. Hal tersebut menjadikan anak mengalami keterlambatan bicara dan bahasa. Kedua, Gadget

${ }^{15}$ America Academy of Pediatrics, Op.cit, 423-6.

${ }^{16}$ Aric, Sigman," Screen Dependency Disorder; A New Challenge for Child Neurology", Journal of the International of the International Child Neurology Association, Mey, 1-15 (2017) 
dapat menyebabkan berkurangnya perhatian anak, bahkan bisa mengarah pada Attension Deficit Hyperactivity Disorder (ADHD) yaitu kesulitan memberikan perhatian, atau kesulitan mengontrol tingkah laku yang tidak sesuai. Ini dapat terjadi pada anak dan menyebabkan mereka menjadi gelisah, tidak dapat fokus, dan mudah terganggu. Perubahan tingkah laku dapat menyebabkan masalah di sekolah dan di rumah. Ketiga, Gadget menimbulkan masalah dalam belajar. Anak-anak belajar banyak hal sebelum usia lima tahun, bahkan bayi belajar lebih cepat daripada anak-anak. Jika mereka menggunakan gadget di waktu seharusnya berkomunikasi dengan orang tua akan menjadikan belajarnya menjadi terbatas. Anak membutuhkan waktu yang cukup untuk berbicara dengan orang tua agar mereka dapat belajar katakata baru dan cara berkomunikasi. Anak membutuhkan orang tua mereka, bukan gadget. Paparan gadget mempengaruhi keterlambatan berpikir dan mengganggu belajar. Keempat, Gadget menimbulkan rasa cemas, gelisah dan khawatir. Cemas, gelisah atau khawatir adalah sebuah ketakutan akan kejadian di masa yang akan datang. Perasaan seperti ini bisa menyebabkan gejala-gejala fisik, seperti berdebar dan semakin cepat denyut jantung. Kondisi ini biasanya membawa pengaruh buruk pada anak. Mereka merasa gugup, malu dan takut dan berusaha untuk menjauhi orang, tempat dan aktifitas. Anak menunjukkan agresi atau tekanan darah naik ketika mereka tidak dapat online dan perasaan ini hilang ketika mereka dapat online kembali. Kelima, Gadget dapat menyebabkan depresi masa anak-anak. Terlalu banyak menggunakan gadget menyebabkan depresi pada anak pada usia tertentu. Anak kecanduan gadget mempunyai potensi menjadi temperamental sangat tinggi. Semula mereka agresif dan temperamen ketika dipisahkan dengan gadget, setelah itu sifat tersebut akan tersimpan dan dalam kondisi apapun, temperamen itu akan muncul. Keenam, Dampak negatif pada karakter. Ini adalah masalah paling besar dalam perkembangan dunia teknologi. Anak-anak menggunakan internet untuk melihat konten dewasa atau negatif daripada untuk mencari website pendidikan. Ini secara praktis mengarah dampak negatif pada karakter yaitu mereka lupa pada nilai moral ${ }^{17}$.

\footnotetext{
${ }^{17}$ Sundus, M, "The Impact of using Gadgets on Children”, Journal Depress Anxiety, Vol. 7 :1-3 (2018).
} 
Selain dampak negatif gadget dari ahli psikologi disampaikan juga dampak negatif gadget menurut pakar media digital yaitu Bill Gates dan Melinda. Menurut mereka seorang anak bisa terkena pengaruh buruk dari internet, rentan menjadi korban dari predator yang berkeliaran di internet, serta berpotensi menjadi korban bullying di dunia digital. Gadget mempengaruhi perkembangan otak anak ke arah yang negatif. Membuat anak menjadi malas bergerak, sehingga sistem motoriknya lambing untuk berkembang. Gadget juga mempengaruhi perkembangan kesehatan mental dan sosialnya. Anak yang kecanduan internet dan gadget tidak bisa bersosialisasi dengan baik, sehingga dia tidak memiliki teman bermain. Gadget membuat anak ketergantungan padanya, sehingga anak tidak bisa bersikap mandiri dalam menyelesaikan masalah. Anak menjadi lamban dalam berpikir. Narasumber menekankan kembali orang tua tidak perlu khawatir anaknya akan gaptek (gagap teknologi) jika tidak diberi gadget saat masih usia dini. Alan Eagle, seorang direktur eksekutif komunikasi di Google menyampaikan "Komputer itu sangat mudah. Kami di Google sengaja membuat perangkat yang ibaratnya bisa digunakan tanpa harus berpikir. Anak-anak toh tetap bisa mempelajari komputer sendiri jika mereka sudah dewasa".

Materi terakhir yaitu cara mencegah anak usia golden age dari kecanduan gadget. Narasumber menyampaikan cara membatasi gadget anak sebagaimana disarakan oleh American Academy of Pediatrisc (APP) yaitu jauhkan perangkat digital (TV, gadget, dan internet) dari kamar anak, awasi apa saja yang dilakukan anak di gadgetnya, jangan pernah menggunakan gadget untuk menenangkan anak yang menangis maupun mengamuk, gunakan media TV, video maupun aplikasi untuk mendiskusikan nilai-nilai yang dianut oleh keluarga, gunakan alasan yang tepat saat akan membatasi anak dari penggunaan TV, media digital dan internet. Selain dari APP, narasumber juga menyampaikan dari theasiaparent dan penelitian Sundus. Ada sembilan cara mencegah kecanduan gadget pada anak di usia golden age.

Pertama, Membatasi durasi penggunaan sebagaimana disarankan The America Academy of Pediatrics (APP) yaitu jangan memberi gadget anak usia di bawah dua tahun, 
anak usia 2-5 tahun boleh menggunakan gadget untuk program edukatif maksimal satu jam sehari dengan pendampingan penuh orang tua, sedangkan anak usia di atas enam tahun boleh memakai gadget untuk program edukatif maksimal dua jam sehari dengan orang tua memastikan konten yang dilihat anak. Kedua, Beri jadwal. Buat kesepakatan jadwal dan berikan aturan yang jelas untuk anak, seperti kapan waktu untuk mengerjakan PR, jam tidur siang, waktu bermain, termasuk kapan waktu menggunakan gadget dan selama berapa lama (sesuai rekomendasi APP). Orang tua harus disiplin dan berkomitmen dengan kesepakatan jadwal dan aturan yang telah dibuat. Ketiga, Jangan beri akses penuh. Letakkan TV atau komputer di ruang keluarga, agar setiap kali menggunakan anak tidak sendirian dan masih dalam pengawasan anggota keluarga yang lain. Jangan serahkan sepenuhnya gadget pada anak, biarkan anak meminta ijin terlebih dahulu jika ingin menggunakannya dan ambil kembali setelah selesai. Pakailah parental control untuk membendung konten-konten yang mengandung materi negatif bagi anak. Kontrol game atau animasi yang ditonton anak. Pastikan anak melihat tayangan sesuai dengan usianya dan memberikan nilai-nilai kebaikan.

Keempat, Tetapkan wilayah bebas gadget. Buat peraturan tidak boleh menggunakan gadget di tempat-tempat atau acara tertentu, seperti di meja makan, kamar tidur, sekolah dan di acara-acara penting keluarga. Semua anggota keluarga, termasuk orang tua juga menepati peraturan ini. Kelima, Ajarkan anak pentingnya menahan diri. Latih anak untuk menahan diri dengan membuat komitmen dan aturan bersama. Orang tua harus mampu melatih anak menahan keinginan bermain gadget di luar jadwal dan waktu yang diperbolehkan dengan menjauhkan gadget dari anak, dan memberinya informasi dampak negatif kebanyakan bermain gadget, serta mengalihkannya ke aktifitas yang lain. Berikan pujian pada anak ketika ia berhasil menahan diri untuk tidak bermain gadget sesuai komitmen dan mengikuti aturan yang telah ditetapkan. Keenam, berikan contoh yang baik. Jangan sibuk menggunakan gadget di depan anak. Jika orang tua menggunakan gadget, maka seperlunya dengan memberikan penjelasan pada anak keperluan orang tua memakai gadget tersebut.

Ketujuh, Buat anak bermain di luar. Doronglah anak untuk bermain di luar bersama teman dan saudaranya, sehingga mereka akan belajar untuk berinteraksi dan 
berkomunikasi dengan anak-anak yang lain melalui berbagai permainan, seperti bermain petak umpet, bermain sepeda, bermain lempar tangkap bola, bermain lompat tali, menyusun balok dan lain sebagainya. Bisa juga bermain dengan hewan peliharaan, seperti kucing, burung atau hewan yang lainnya. Ini juga akan melatih penglihatan jarak jauh dan mengurangi peluang terjadi miopi atau rabun jauh. Kedelapan, Jangan jadikan gadget sebagai baby sitters. Jangan menjadikan anak sibuk dengan gadget agar orang tua dapat melakukan aktifitasnya dengan tenang, alihkan mereka agar tenang dengan menggunakan mainan kreatif, buku-buku cerita, puzzle, dan buku-buku menggambar atau mewarnai. Sesekali luangkan waktu bermain bersama anak. Hadirnya orang tua begitu berkesan bagi anak. Anak bisa merasakan adanya kehangatan, perhatian dan kasih sayang orang tua saat bermain, bersendagurau bersama. Bermain bersama akan mempererat hubungan orang tua dan anak. Kesembilan, Memastikan anak memiliki waktu tidur yang cukup Anak-anak harus cukup tidur satu hari sepuluh jam. Tidur nyenyak akan membantu pemulihan dari ketegangan mata dan untuk mengefisienkan otak. Tidur nyenyak juga dibutuhkan untuk kesehatan yang baik.

Setelah semua materi disampaikan, selanjutnya adalah forum tanya jawab. Para peserta antusias untuk mengajukan pertanyaan. Pertanyaan pertama dari Bu Dewi yaitu bagaimana menjadikan anak tidak hanya bermain HP sementara orang tua juga bekerja, sehingga di rumah hanya dengan pengasuh. Narasumber menjawab bahwa mengasuh dan mendidik anak adalah kewajiban orang tua. Jika orang tua bekerja, maka orang tua bisa bekerjasama dengan pengasuh yang ada di rumah untuk mengkondisikan agar anak tidak bermain HP. Disini pentingnya orang tua untuk bisa memahamkan pengasuh tentang model pendidikan yang diinginkan untuk dilakukan pengasuh pada anak selama orang tua tidak ada di rumah. Selanjutnya pertanyaan kedua dari Bu Ida yaitu ada anak usia dua tahun belum bisa bicara, memang sejak kecil diberi HP dan di rumah hanya dengan pembantu yang cenderung diam. Secara fisik tidak ada hambatan perkembangan. Tidak bisa bicara apa karena gadget? . Narasumber memberikan jawaban untuk pertanyaan kedua yaitu jika anak tidak memiliki hambatan fisik, termasuk organ bicaranya (mulut, bibir, lidah), akan tetapi mengalami keterlambatan bicara dan bahasa, maka bisa di cek dari segi makanan yang dikonsumasinya, apakah selama ini hanya makan makanan halus, 
apa masih minum dari dot dan lain sebagainya. Jika anak makan dan minum sesuai usia perkembangannya, yaitu makan juga makanan padat, termasuk minum dari gelas maka bisa perlu dicek stimulasi yang diberikan oleh lingkungan sekelilingnya. Dari informasi orang tua bekerja dan di rumah hanya dengan pengasuh yang cenderung pendiam, maka kemungkinan anak tersebut terlambat bicara dan bahasa karena kurang stimulasi, solusinya orang tua harus memberikan banyak stimulasi karena anak akan bisa memproduksi kata jika mendapatkan banyak masukan perbendaharaan kata ke dalam benaknya. Hal ini juga sebaiknya dikomunikasikan ke pengasuh agar bisa mendukung untuk memberikan stimulasi bicara selama orang tua bekerja.

Pertanyaan ketiga dan empat berasal dari Bu Ninin yaitu selama pandemi anak daring dan menggunakan HP, kadang keterusan melihat HP dan saat diingatkan suarnya keras. Apa sikapnya yang demikian karena HP, serta bagaimana ciri kecanduan gadget?. Narasumber menjawab gadget salah satunya HP memang memberikan pengaruh bagi anak, apalagi jika anak dalam masa meniru. Anak akan meniru apa yang dilihat dan didengarnya dari HP. Sekali melihat HP, maka akan ada keinginan melihat lagi karena memberikan pengaruh adiksi. Ketika anak dilarang atau dibatasi menggunakan HP, maka yang muncul adalah emosi marah. Dalam kondisi seperti ini, maka orang tua memberikan penjadwalan yang disiplin di waktu kapan dan tontonan apa yang boleh dan tidak boleh dilihat anak. Orang tua harus konsiten dengan apa yang dijadwalkan bersama anak jika sudah bisa diajak berkomunikasi. Selain membuat jadwal, orang tua juga memberikan pemahaman pengaruh negatif gadget bagi anak dengan bahasa sesuai dengan kemampuan berpikir anak. Adapun ciri kecanduan gadget sebagaiman disampaikan dalam materi yaitu ketika anak sangat tergantung pada gadget dan tidak bisa dipisahkan, jam penggunaanya melebihi standar yang seharusnya sesuai arahan APP dan keasyikan anak bersama gadget menjadikannya melupakan tugas dan aktifitas yang harusnya dilakukannya. Peserta yang bertanya merasa puas dengan jawaban yang diberikan narasumber.

Di akhir acara dilakukan evaluasi. Peserta diminta memberikan penilaian dari lima pernyataan yang diberikan oleh narasumber. Penilaian yang disediakan yaitu sangat tidak setuju, tidak setuju, netral, setuju, dan sangat setuju. Pernyataan pertama yaitu kelas digital parenting ini menarik. Ada tiga orang yang menyampaikan sangat setuju, tujuh 
orang menyampaikan setuju dan satu orang menjawab netral, tidak ada yang menjawab tidak setuju dan sangat tidak setuju. Berdasarkan hal ini, maka 90\% peserta berpendapat bahwa acara kelas digital parenting ini menarik. Adapun untuk pernyataan kedua yaitu acara ini sesuai harapan dan bermanfaat. Ada satu yang menyatakan sangat setuju, sembilan setuju, satu menjawab netral, tidak ada yang menjawab tidak setuju dan sangat tidak setuju. Berdasarkan hal ini, maka 90\% peserta berpendapat bahwa acara kelas digital parenting sesuai harapan dan bermanfaat. Pernyataan ketiga yaitu kelas digital parenting menambah pengetahuan peserta . Ada tiga yang menyatakan sangat setuju, tujuh orang setuju, satu netral, tidak ada yang menjawab tidak setuju dan sangat tidak setuju. Berdasarkan hal ini, maka 90\% peserta menyatakan bahwa kelas digital parenting bermanfaat untuk menambah pengetahuan mereka tentang digital parenting. Pernyataan keempat cara mencegah kecanduan gadget yang disampaikan mudah dilakukan. Peserta yang menyatakan setuju tujuh orang, dan yang menyatakan netral 4 orang, tidak ada yang menjawab sangat setuju, tidak setuju dan sangat tidak setuju. Berdasarkan data ini maka 63,63 \% peserta menyatakan cara mencegah kecanduan gadget di masa golden age yang disampaikan narasumber mudah dilakukan. Pernyataan kelima, peserta akan segera menerapkan pengetahuan yang didapatkan hari ini. Sebanyak satu peserta menyatakan sangat setuju, delapan orang menyatakan setuju dan dua orang menyatakan netral. Berdasarkan data ini, maka $81,81 \%$ menyatakan setuju untuk segera menerapkan pengetahuan yang didapatkan hari ini.

\section{PENUTUP}

Dari hasil penelitian dapat disimpulkan kelas digital parenting bertema cara mencegah kecanduan gadget di masa golden age di Sekolah Inklusi Pesantren Anak Shalih(PAS) Baitul Qur'an Ponorogo telah dilaksanakan dengan baik. Peserta antusias mengikuti acara dari awal sampai akhir. Pengetahuan peserta tentang digital parenting juga semakin bertambah. Disarankan bagi penelitian selanjutnya untuk menambah variabel lain untuk mendapatkan hasil penelitian yang lebih komprehensif dan menggunakan metode bervariasi dalam menyampaikan materi agar lebih menarik. 


\section{DAFTAR PUSTAKA}

American Academy of Pediatrics Committee on Public Education. Children, Adolencents, and Television. Pediatr. 107 (2) :423-6 (2001).

Azhar, R. (2019, 18 Desember). 70 Persen Anak Kecanduan Gadget. Diunduh pada 19 Februari 2020, dari https://bengkuluekspress.com/70-persen-anak-kecanduangadget.

Kompas. (2018,23 Juli). Kecanduan Gadget Ancam Anak-anak. Diakses pada 10 Juli 2020 dari https://kominfo.go.id/content/detail/13547/kecanduan-gawai -ancamanak-anak/0/sorotan-media.

Laely, Khusnul dkk.,"Parenting Pengasuhan di Era Digital dalam Rnagka Mendukung Terwujudnya PKBM (Pusat Kegiatan Belajar Masyarakat) di Daerah Miskin", The 6th University Research Colloqium. Universitas Muhammadiyah Magelang. 1- 7 (2017).

Maisari, Sri dan Purnama, Sigit, "Peran Digital Parenting terhadap Perkembangan Berpikir Logis Anak Usia 5-6 tahun di RA Bunayya Giwangan", Jurnal Pendidikan Anak, Vol 5, No.1 (2019).

Mascheroni, Giovanna, dkk, Digital Parenting: The Challengs for Families in The Digital Age. Nordocom University of Gothenburg: The International Clearinghouse on Children, Youth and Media, 2018.

Ramadhani, M.R, Fernanda,R., Sari, R., dan Lubis, H, "Peran Pola Asuh Orang Tua dalam Membentuk Karakter Peduli Lingkungan," Jurnal Psikostudia, Vol.7, No.2, 61-70 (2018).

Rode, Jennifer A. Digital Parenting: Designing Children's Safety dalam British Computer Society, London, 6 (12) : 244-251 (2009).

Faisal, Sanapiah . Format-format Penelitian Sosial. Jakarta: Rajawali Press, 1992.

Sanders, M.R, "Triple P-Positive Parenting Program as a Public Health Approach to Strengthening Parenting", Journal of Family Psychology, 506-517 (2008).

Sanders, M.R., Dadds, C.M., dan Turner, K.M. Theoretical, Scientific and Clinical Foundations of the Triple P-Positive Parenting Program: A Population Approach to the Promotion of Parenting Competence. Queensland: The University of Queensland,2003,

Sigman, A, "Screen Dependency Disorder; A New Challenge for Child Neurology", Journal of the International of the International Child Neurology Association, Mey, $1-15$ (2017) 
Suhardi, T dan Utami, E. Ayah \& Bunda, Mengatasi Kecanduan Gadget pada Anak. Semarang: Syalmahat Publishing, 2019.

Sundus, M, "The Impact of using Gadgets on Children. Journal Depress Anxiety", Vol. 7, :1-3 (2018)

Zaini, M \& Soenarto, "Persepsi Orangtua terhadap Hadirnya Era Teknologi Digital di Kalangan Anak Usia Dini”, Jurnal Obsesi: Jurnal Pendidikan Anak Usia Dini Vol 3, No 1, 254-264 (2019)

Zhallina,Nuryus. (2019, 11 Desember). Kecanduan Gadget pada Usia Dini Semakin Menghawatirkan. Diakses pada 10 Juli 2020 dari (https://www.suara.com/yoursay/ 2019/12/11/135739/kecanduan-gadget-pada-usia-dinisemakin-menghawatirkan). 